\title{
Price and Income Elasticities of International Trade: Case of Jordan
}

\author{
Ziad Mohammed Abu-Lila ${ }^{1}$ \\ ${ }^{1}$ Economics Department, Yarmouk University, Irbid, Jordan \\ Correspondence: Ziad Mohammed Abu-Lila, Economics Department, Yarmouk University, Irbid, Jordan. E-mail: \\ abu-lila@yu.edu.jo
}

Received: June 13, 2014

Accepted: August 4, 2014

Online Published: September 25, 2014

doi:10.5539/ijef.v6n10p250

URL: http://dx.doi.org/10.5539/ijef.v6n10p250

\begin{abstract}
The aim of this study is to investigate empirically the economic determinations of Jordan's external trade, through estimating the price and income elasticities of international trade. To do so, the demand functions for both exports and imports will be specified and estimated using time series data of Jordanian economy for the periods 1980-2012.

In this study, we show that, the sum of price elasticities of import and export demand exceeds one for Jordan which satisfied the Marshall-Lerner condition. The results of trade elasticity indicate that devaluation is an appropriate policy for Jordan to promote export revenues and improve trade balance.
\end{abstract}

Keywords: income elasticity of exports, income elasticity of imports, price elasticity of exports, price elasticity of imports, international trade

\section{Introduction}

Starting in the 1980s, many developing nations that had earlier followed an import substitution industrialization strategy began to liberalize trade and adopt an outward orientation. The reforms were spurred by the debt crisis that began in 1982 and by the evident success of the outward-oriented countries (Salvatore, 2001).

Throughout increasing the openness degree and countries efforts to maximize benefits from international trade, this makes the import and export demand specifications essential to determine the welfare gains from trade. And one of the most important issues in open countries is to determine the effects of income and relative prices on international trade.

In general, the Jordanian economy as many other less developed countries (LDCs) is widely open economy. This affects the high degree of openness (the ratio of foreign trade to GDP): This ratio was $72 \%$ in 1980 , reached about $89 \%$ in 2012 , ranged between $48 \%$ and $112 \%$ during $1980-2012$. The progress of this ratio over time for Jordan is presented in Figure 1.

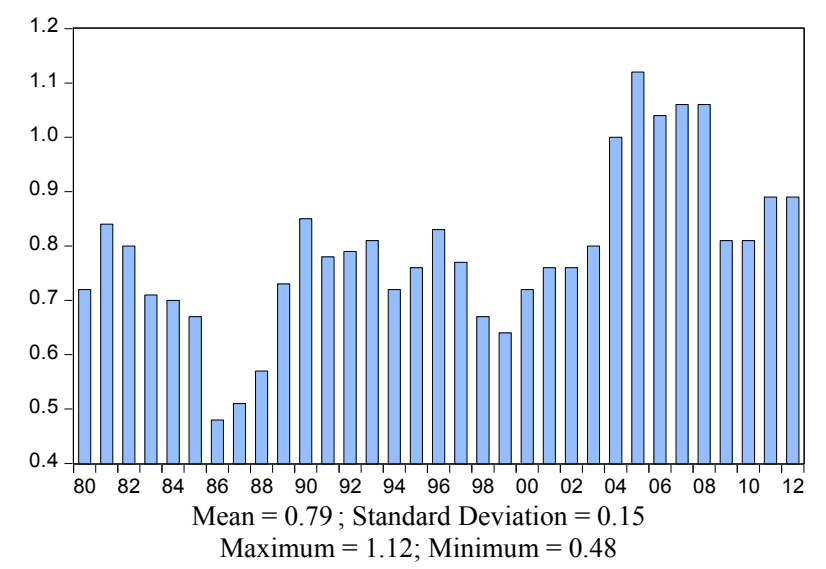

Figure 1. The ratio of foreign trade to GDP 
Moreover, and as a result of obvious gap between imports and exports, trade balance has experienced deficit. The deficit amounted to JD 481 millions in 1980, exceeded one billion Jordanian dinar in 1992 and reached JD 7.5 billion in 2012. The progress of the trade balance deficits over time for Jordan is presented in graph 2.

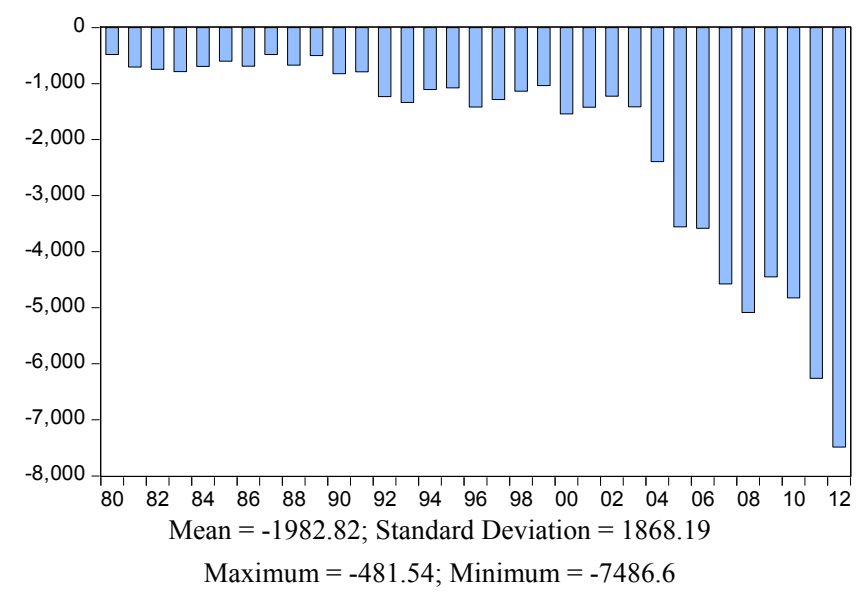

Figure 2. Trade deficit

Over the past years, Jordan faced multiple external shocks; the global economic and financial crisis, then the European debt crisis, the Arab spring repercussions which affected the Egyptian gas flows to Jordan, and finally the Syrian crisis which resulted in an accelerated inflow of Syrian refugees. These unfavorable developments have added several pressures on the Jordanian economy which adversely affected the performance of the balance of payments. (Central Bank Annual Report, 2012). This study applies the Dummy variable test to examine the stability of elasticities over this period (after 2008), since and based on the Marshall-Lerner condition ,the stability of the trade elasticity are useful benchmarks for predicting the potential impact of a change in the real exchange rate on economy's trade balance.

All these facts have been realized by Jordanian successive economic development plans. Policies have targeted import substitution and export promotion strategies for the hope of reducing the trade deficit. However, the overhang of trade deficit cast serious doubts around various policy measures that have been employed by decision markers.

\subsection{The Importance}

Our study attempts to estimate the income and price elasticities of international trade to determine the effect of income, relative prices and then the real exchange rate on Jordanian foreign trade. In order to achieve this objective, the study uses annually time series data for Jordan over the periods 1980-2012 which is extracted from various sources such as the Statistical Database of Central Bank of Jordan (CBJ), International Financial Statistics (IFS).

The rest of the paper is organized as follows: the second section gives an overview of the relevant economic literature and the theoretical background, while the third provides a profile of the goods traded and the major markets for Jordanian foreign trade, and the fourth section presents the econometrical model, defines its variables, investigates data sources, limitations, and deals with related empirical issues. The empirical results are reported in the fifth section, while the last section concludes and draws policy implications.

\section{The Economic Literature Review}

The estimation of income and price elasticity of trade is consequently the heart of innumerable studies. Price elasticities are particularly important for estimating the effects on trade flows of changes in real exchange rates and for determining to which degree they adjust to these changes. The "elasticities" approach of the econometric specifications of import and export demand functions has always been used in international economics to determine the causes of trade because of its capacity both to explain the past and to forecast and, consequently, plan the future (Via, 2011).

The role of income and prices in international trade has been the focus of several studies. Prais (1962), one of the oldest studies that estimated the income and price elasticity for world trade the early estimations models, is 
examined by Taplin (1973). Multi-country case has been gauged by Deardorff and Stern (1978). Special attention should be paid to trade surveys by Leamer and Stern (1970), Stern et al. (1976), the works by Chipman (1985) and Goldstein and Khan (1985); these studies identify, summarize, and evaluate the main methodological and policy issues that have surrounded the estimation of trade equations.

Goldstein and Khan (1985) presented a "bare-bones" imperfect substitute model of a country's imports from, and exports to, the rest of the world:

$$
\begin{gathered}
I^{d}=f(Y, P I, P) \text { where } f_{Y}>0, f_{P I}<0, \text { and } f_{P}>0 \\
X^{d}=g(W Y, P X, W P) \text { where } g_{W Y}>0, g_{P X}<0, \text { and } g_{W P}>0
\end{gathered}
$$

The first equation determines the quantity of imports demanded $\left(\mathrm{I}^{\mathrm{d}}\right)$ by the country from the rest of the world as a function of its income (Y), the domestic price of imports (PI) in this country, and the domestic general price level $(\mathrm{P})$. The second equation determines the demand for exports $\left(\mathrm{X}^{\mathrm{d}}\right)$ of the same country by the rest of the world as a function of world income (WY), export prices (PX), and world general price level (WP).

The main characteristics of the imperfect substitute's model can be summarized as follows: in accordance with conventional demand theory, the consumer is postulated to maximize his utility subject to a budget constraint. The resulting demand functions for imports and exports thus representing the quantity demanded as a function of the level of money income in importing region, the imported good's own price, and the price of domestic substitute.

Many researchers have adopted several specifications of demand for imports and exports. Some researchers introduced dummy variables to account for the presence or the absence of a devaluation to study its effects on prices and quantities of international trade. Others have treated static and dynamic effects of exchange rate changes on trade.

Based on that models that is employed in previous studies, the imports function take the following form:

$$
\log (M)=a+b \log \left(\frac{P M}{P}\right)+c \log (Y)+\varepsilon
$$

Where imports were estimated as a function of income and relative prices, this model is used to estimate the elasticities in the long-term and short-term, by using different econometrics models; OLS, cointegration, 2SLS and etc., (Via, 2011).

In an earlier work, Khan (1974) studied the demand for exports and the demand for imports for a group of LDCs. He specified his model equations as follows:

$$
\begin{gathered}
\log M=f\left(\log \left(\frac{P M}{C P I}\right), \log (G D P)\right) \text { where } f_{\frac{P M}{C P I}}<0 \text {, and } f_{G D P}>0 \\
\log X=f\left(\log \left(\frac{P X}{W C P I}\right), \log (W G D P)\right) \text { where } g_{\frac{P X}{W C P I}}<0 \text {, and } g_{W G D P}>0
\end{gathered}
$$

Where $\mathrm{M}$ is the demand for imports, $\mathrm{X}$ is the demand for exports, $\mathrm{PM}$ and PX are prices of imports and exports; respectively, and CPI and WCPI are domestic and world prices, and GDP and WGDP are domestic and foreign incomes.

A study in Jordan, Talafha (1988) found that exports were inelastic exchange rate which was influenced by imports. Imports were significantly dependent on GDP, and it insensitive to exchange rate changes yet imports of raw materials and consumer goods were negatively influenced by the exchange rate of Jordanian Dinar.

Senhadji and Montengro (1999) argued that the higher the income elasticity of demand for exports, the more powerful exports will be as an engine of growth. In addition, the higher the price of export elasticity is, the more competitive the international market for exports of the particular country is. Thus, numerous successes will be a real devaluation in promoting export revenues. Furthermore, Senhadji and Motengro found an empirical support for elastic exports incomes for developing countries which led to concluding that exports could be used as an engine of growth in these countries while price elasticities were on the average close to zero in the short-run, and to one in the long-run.

Chinn (2003) examined the stability of import and export demand which functioned for the U.S over the periods 1975-2001. He found an empirical support for stable and long-run relationship for exports. He concluded that exports had a stable relationship with real exchange rate and real world income. But he found little support for a stable demand for imports. Furthermore, the low price elasticity of demand for imports suggested that large devaluation of the dollar was required to bring an improvement in the U.S trade balance. 
Uz, I (2010) investigated the long-run bilateral trade elasticities of Turkey and its major trading countries. He found that, in the long run, Turkish bilateral trade was inelastic (with varying sign). Thus, the devaluation or revaluation of the Turkish Lira should be expected to have only a limited impact on Turkey's trade balance, and Turkish trade had an elastic income in the long run but inelastic income in the short run.

From empirical trade works on demand for exports and imports, four conclusions stand out. The first one is that the sum of price elasticities of import and export demand invariably exceeds one for industrial countries. Second, short run elasticities are always less than long run ones. Third, income elasticities are much higher than price elasticities especially in the short run. And finally, if imports and exports are categorized into their components, then there will be significant differences in price and income elasticities across commodity groups (Jones \& Kenen, 1985).

The above conclusions have some important policy implications. The first is that Marshall-Learner condition will hold. This means supply elasticities are infinite, then devaluation will improve terms of trade and hence the trade balance. Moreover, the J-Curve phenomenon will be supported. This says that an exchange rate policy (i.e., devaluation) worsens the trade balance in the short-run but the net effect in the long run will be favorable (Goldstein \& Khan, 1976, 1978, 1985).

\section{Jordanian Foreign Trade}

The nineties witnessed huge changes in the global economy through increasing the degree of trade liberalization; these changes gave the foreign trade new dimensions which required studying and analyzing. Also, there is important role for trade in encouraging foreign investment since it is the best way to overcome the problem of the small size of the domestic market. Therefore, the country tries to remove all obstacles that could limit the flow of trade through trade liberalization policies.

In Jordan, these policies play an important role in the development of exports and open new channels for Jordanian goods. In addition, such policies helped the Kingdom to cover the needs of imported goods especially essential ones - that cannot be produced locally.

With these policies the reviewer can observe some changes in the volume of Jordanian exports and imports. At the level of exports, recent years have seen a growth in exports from JD 120.11 million in 1980 to JD4804.81 million in 2013 with average growth rate 12.91\%. On the other side, the imports increased from JD715.98 million in 1980 to JD15523.49 million in 2013 with average growth rate $10.52 \%$.

Table 1 summarizes Jordan's external trade flows with its four largest trading partners in 2013-Arab countries, European Countries, USA, China and India. Table 2 provides information on the major products of international trade.

Based on the following tables, there are several observations on Jordanian Foreign Trade:

1). The high proportion of imports to GDP (on average 59.93\%).

2). The low proportion of exports to GDP (on average 19.27\%).

3). The value of imports is greater than the value of exports, which led to deficient in the trade balance.

4). The continuing decline in the relative importance of consumer goods in imported goods. And in contrast the high relative importance of consumer goods in exports, as a result of substitution between domestic goods and imported.

5). Rise in the relative importance of raw materials and intermediate goods imported.

6). Geographic concentration of Jordanian exports.

Table 1. External trade pattern, 2013

\begin{tabular}{lcccc}
\hline Exports & $\begin{array}{c}\text { Percentage of } \\
\text { GDP }\end{array}$ & $\begin{array}{c}\text { Percentage of Total } \\
\text { Exports }\end{array}$ & Imports & \multicolumn{2}{c}{$\begin{array}{c}\text { Percentage of } \\
\text { GDP }\end{array}$} & $\begin{array}{c}\text { Percentage of } \\
\text { Total Imports }\end{array}$ \\
\hline Total Exports & 20.15 & 100 & Total Exports & 65.08 \\
Of which: & & & Of which: & 100 \\
Arab Countries & 10.78 & 53.51 & Arab Countries & 20.24 \\
European Countries & 0.82 & 4.06 & European Countries & 17.37 \\
USA & 3.55 & 17.64 & USA & 4.05 \\
India & 1.47 & 7.3 & China & 6.65 \\
\hline
\end{tabular}

Source: Central Bank of Jordan. 
Table 2. Product composition of international trade, 2013

\begin{tabular}{lclc}
\hline & Percentage of Total & & Percentage of Total \\
\hline Domestic Exports of goods & 100 & Imports of goods & 100 \\
Consumer goods & 52.56 & Consumer goods & 26.38 \\
Crude Materials \& Intermediate Goods & 43.97 & Crude Materials \& Intermediate Goods & 58.65 \\
Capital goods & 3.46 & Capital goods & 13.46 \\
Total of The above & 99.99 & Total of The above & 98.49 \\
\hline
\end{tabular}

Source: Central Bank of Jordan.

And with regard to the relationship between trade balance and real exchange rate, the correlation test suggests that the movements in Jordan's real exchange rate (RER) are negatively correlated with its trade balance in percentage of GDP, as represented in graph 3.

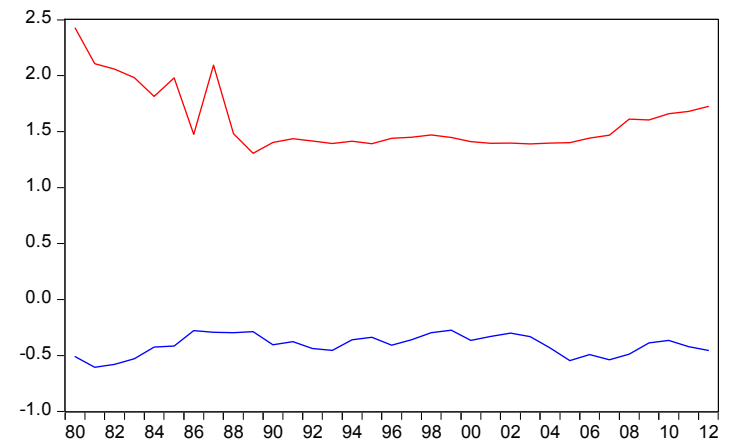

$$
\text { - TBP - RER }
$$

Figure 3. The relationship between real exchange rate (RER) and percentage of trade balance in GDP

\section{The Econometrical Model}

To achieve the aim of this study and based on the economic literature, the demand for imports and exports is specified as follows:

$$
\begin{aligned}
& M=f\left(G D P, \frac{W C P I}{C P I}\right) \\
& X=g\left(W G D P, \frac{P X}{W C P I}\right)
\end{aligned}
$$

The long-run and short-run elasticities of imports and exports can be derived from previous functions after converting it to logarithm form as follows:

$$
\begin{array}{r}
\log M=f\left(\log \left(\frac{W C P I}{C P I}\right), \log (G D P)\right) \\
\log M=f\left(\log \left(T O T^{*}\right), \log (G D P)\right) \\
\log X=g\left(\log \left(\frac{P X}{W C P I}\right), \log (W G D P)\right) \\
\log X=g(\log (T O T), \log (W G D P))
\end{array}
$$

The variable models are defined as follows: $\mathrm{X}$ is the value of exports, $\mathrm{M}$ is the value of imports, $\mathrm{PX}$ is the unit value of exports, CPI is the domestic consumer price index, WCPI is the world consumer price index, GDP is gross domestic product at current prices, WGDP is the world gross domestic product, TOT is a term of trade and it is calculated as (PX/WCPI) and finally, TOT* is the inverse of term of trade (WCPI/CPI). The purpose of the dummy variable (Dum) is to capture the effect of the external shocks on the stability of elasticities. (Dum) takes the value of one over the periods 2008-2012. Otherwise, (Dum) takes the value of zero.

The expected signs of the parameters are as follows: 


$$
\frac{\partial \log M}{\partial \log G D P}>0, \frac{\partial \log M}{\partial \log T O T^{*}}<0, \frac{\partial \log X}{\partial \log W G D P}>0 \text {, and } \frac{\partial \log X}{\partial \log T O T}<0
$$

The income elasticities are expected to be positive and those prices are to bear negative signs since they reflect a substitution effect.

Any regression involving time series might give results that are spurious in the sense that it lacks any meaningful relationship on economic grounds. Spurious or nonsense regression arises when a nonstationary time series is regressed on one on more nonstationary time series (Gujarati, 2003). Therefore, the econometric methodology firstly examines the stationarity properties of the univariate time series. The present study uses the Augmented Dickey-Fuller (ADF) unit root test to examine the stationarity of the data series.

Secondly, time series have to be examined for cointegration. Since if the variables of the study are non-stationary at level and all are stable at the same degree, the study should be checking the stability of the estimated errors of this regression to identify long-run relationships between two or more variables. Cointegration analysis is important because if two non-stationary variables are cointegrated, the model that uses to estimate the short run elasticities must include residuals to make adjustment to long run value, i.e. error correction model (ECM).

\section{The Empirical Results}

The results of ADF test detect that the time series used in this study are non-stationary on level, by taking into consideration intercept, by time trend, or without, depending on the shape of data. The results of the test refer to stationarity of the variables at first difference at 5\% significance level, as shown in Table 3 . Consequently, these variables are integrated of degree one, the test used 1 period as lag to ensure that there is no autocorrelation in this model based on minimum value of the AIC test.

Table 3. ADF unit root test (at first difference)

\begin{tabular}{lccc}
\hline \multirow{2}{*}{ Variables } & \multicolumn{2}{c}{ First Difference } & \multirow{2}{*}{ Lag } \\
\cline { 2 - 3 } & ADF Value & Critical Value & \\
\hline $\log (\mathrm{M})$ & -5.21 & -3.56 & 1 \\
$\log (\mathrm{X})$ & -6.28 & -3.56 & 1 \\
$\log (\mathrm{GDP})$ & -2.72 & $-2.62^{*}$ & 1 \\
$\log (\mathrm{WGDP})$ & -3.7 & -3.57 & 2 \\
$\log (\mathrm{TOT})$ & -3.99 & -2.96 & 1 \\
$\log \left(\right.$ TOT $\left.^{*}\right)$ & -3.72 & -3.56 & 1 \\
\hline
\end{tabular}

Note. * Stationary at $10 \%$ level. Stationary with trend, or intercept, or without depends on the shape of data.

Since the variables of the study are non-stationary at level and all are stable at the first difference, the study can be applied on cointegration test to check the stability of the estimated errors of this regression (i.e., exports equation). Based on Table 4, which shows the results of cointegration test for exports equation that indicate-by using trace test-there is one cointergrated vector, where the null hypothesis $r=0$ was rejected at $5 \%$ significance level, and results of Max test coincided with this result. Therefore, it can be inferred to the existence of a long-run relationship between exports and its determinants that used in this study.

Table 4. Johansen cointegration test for exports equation

\begin{tabular}{ccccc}
\hline $\mathbf{H}_{\mathbf{0}}$ & $\tau_{\text {Trace }}$ & $\mathbf{5 \%} \mathbf{C . V}$ & $\tau_{\text {Max }}$ & $\mathbf{5 \%} \mathbf{C . V}$ \\
\hline $\mathrm{r}=0$ & 36.77 & 24.28 & 25.45 & 17.8 \\
$\mathrm{r} \leq 1$ & 11.22 & 12.32 & 10.91 & 11.22 \\
$\mathrm{r} \leq 2$ & 0.31 & 4.13 & 0.31 & 4.13 \\
\hline
\end{tabular}

Based on the Johansen cointegration test, the estimated cointegration has been vectored after correcting the sign for all coefficients of the variables as follows (t-statistics in parentheses):

$$
\log (\mathrm{X})=1.34 \log (W G D P)-2.34 \log (T O T)
$$


As this equation shows, the elasticity of export with respect to foreign income is about 1.34 suggesting that if foreign income goes up by one percent, on average, the export goes up by about 1.34 percent; this is consistent with the findings of Senhadji and Montengro (1999).

Thus, on one hand, exports are very responsive to change in foreign income. On the other hand, the elasticity of export with respect to term of trade is $(-2.34)$, and that means, if the term of trade TOT rises by one percent the total export will flows down by 2.34 percent (The main items in Jordanian exports are consumer goods and chemical materials, and it has many substitute goods). Also, the high price elasticity is explained by the low proportion of high-technology goods exported by Jordan.

And on the other hand, imports are the results of trace and maximum eigenvalue test also suggest that there is one cointegration vector between imports and its determinants. The null hypothesis of $r=0$ is rejected at $5 \%$ significance level, because of the computed values of both tests is greater than the critical values at $5 \%$ level, as table 5 indicates. But the null hypothesis of $r \leq 1$ cannot be rejected at the same level of significance. Therefore, based on both tests, we concluded that there exists a single cointegrating vector in the model.

Table 5. Johansen cointegration test for imports equation

\begin{tabular}{ccccc}
\hline $\mathbf{H}_{\mathbf{0}}$ & $\tau_{\text {Trace }}$ & $\mathbf{5 \%} \mathbf{C . V}$ & $\tau_{\text {Max }}$ & $\mathbf{5 \%} \mathbf{C . V}$ \\
\hline $\mathrm{r}=0$ & 41.53 & 24.28 & 31.39 & 17.8 \\
$\mathrm{r} \leq 1$ & 10.15 & 12.32 & 8.87 & 11.22 \\
$\mathrm{r} \leq 2$ & 1.27 & 4.13 & 1.27 & 4.13 \\
\hline
\end{tabular}

The normalized cointegration coefficient and correct sign for all the variables is (t-statistics in parentheses):

$$
\log (M)=1.01 \log (G D P)-0.2 \log \left(T O T^{*}\right)
$$

The estimated income elasticity is positive, as expected, and statistically significant at $1 \%$ level, and it is greater than one. This means, the percentage change in imports is greater than the percentage change in income; therefore, it is difficult for an economic increase to avoid trade deficits.

The long run price elasticity is negative and statistically significant at the $5 \%$ level. The estimated price elasticity for total imports may appear to be low, and this may be due to aggregation (imports are not classified into their components) or due to the type of imports (necessary or luxury goods); this result is in line with the findings of Chinn (2003).

Based on the long-run cointegration relationship, the error-correction term $\mathrm{ECM}_{\mathrm{t}-1}$ derived and used in the following error correction model for exports:

$$
\Delta \log (X)=-0.15 \Delta \log \left(X_{t-1}\right)+1.31 \Delta \log \left(W G D P_{t-1}\right)-0.12 \Delta \log \left(T O T_{t-1}\right)-0.02 \mathrm{ECM}_{t-1}
$$

The estimated error-correction model for export equation has expected signs but it is insignificant, and the speed of adjustment is to run long equilibrium (0.02).

The short run elasticity of export with respect to foreign income is 1.31 , and that means, if the foreign income increases by $1 \%$ the total export will increases by $1.31 \%$. While the short-run elasticity of export with respect to the term of trade is $(-0.12)$, the lower the price elasticity is, the less competitive is the international market for exports. However, the error correction model for import is estimated as:

$$
\Delta \log (M)=0.28 \Delta \log \left(M_{t-1}\right)+0.66 \Delta \log \left(G D P_{t-2}\right)-0.58 \Delta \log \left(T_{O}{ }_{t-1}\right)-0.04 \mathrm{ECM}_{t-1}
$$

The ECM has a correct sign but statistically insignificant at $5 \%$ level. Thus, the value of $\mathrm{ECM}_{\mathrm{t}-1}$ parameter decides how quickly the equilibrium is restored. However, the short run elasticities of imports with respect to income and prices are 0.66 and $(-0.58)$ respectively, that means the imports will increases by $0.66 \%$ as a results of increases in GDP in second period by $1 \%$, and on the other side, the imports will decreases by $0.58 \%$ as a results of increases in term of trade by $1 \%$. And the variables have the expected signs (the positive effect of GDP starts after two periods based on the impulse response function); this is consistent with the findings of Senhadji and Montengro (1999).

The serial correlation LM test applied for ECM with 2 lags in the test equation, the results strongly reject the null hypothesis of no serial correlation. Also, the study employed the White test to detect the existence of Heteroskedasticity in the outputs of ECM; the statistics of test accept the null hypothesis of Homoskedasticity. 
Also, the study estimates the error correction model and cointegration test after adding dummy variable to test the stability of coefficients for term of trade and income. The test results for the error correction equations with dummy variable indicate that the elasticities are mostly stable in the long run and unstable in the short run . This may not be surprising as it was a volatile period marked by large external shocks, such as the global economic and financial crisis, then the European debt crisis, the Arab spring repercussions which affected the Egyptian gas flows to Jordan, and finally the Syrian crisis which resulted in an accelerated inflow of Syrian refugees.

\section{Conclusions and Policy Uses}

The main conclusions of this paper are the following: first, the long-run elasticities are greater than the short run elasticities. Second, the sum of price elasticities of demand for imports and exports, in absolute term, is greater than one for Jordan 2.54. This result suggests that the Marshall-Lerner condition does hold for Jordan. Third, the high price elasticity of exports that explained by the low proportion of high-technology goods exported by Jordan. Fourth, the income elasticity of demand for export is excess than one (1.34). Fifth, the demand for imports is elastic with respect to income (1.01).

The above conclusions have some important policy implications:

- The higher the income elasticity of demand for export is (1.34), the more powerful export will be as an engine of growth. Consequently, growth in its partner countries will refer to growth in domestic countries at least the same magnitude of its exports.

- The unitary income elasticity of imports may make it difficult for an economic increase to avoid trade deficits.

- The econometric evidence indicates that devaluation is an appropriate policy for Jordan to promote export revenues and improve trade balance, based on the price elasticity of exports $(-2.34)$ and the price elasticity of imports (-0.2) that satisfied the Marshall-Lerner condition.

\section{References}

Central Bank of Jordan, Yearly Statistical Series. (1964-2010). Central Bank of Jordan: Statistical data bases, 2010. Retrieved from http://statisticaldb.cbj.gov.jo/index?lang=en

Chinn, M. (2003). Doomed to Deficit? Aggregate U.S. Trade Flows Reexamined. NBER WP \# 9521.

Chipman, S. J. (1985). Estimation of Net-Import Demand Functions for the Federal Republic of Germany, 19591982. In H. Giersch (Ed.), Probleme und Perspektiven der weltwirtschaftlichen Entwicklung, Jahrestagung des Verein für Socialpolitik, Gesellschaft für Wirtschaftsund Socialwissenschaften in Travemünde vom 1719. September 1984, Neue Folge, Band 148, Berlin: Duncker \& Humblot, 197-213.

Deardorff, A., \& Stern, R. M. (1978). The Terms-of-Trade Effect on Expenditure: Some Evidence from Econometric Models. Journal of International Economics, 8, 409-414. http://dx.doi.org/10.1016/0022-1996(78)90004-1

Dickey, D. A., \& Fuller, W. A. (1979). Distribution of the Estimators for Autoregressive Time Series with a Unit Root. Journal of the American Statistical Association.

Goldstein, M., \& Khan, M. (1985). Income and price effects in foreign trade. In Jones \& Kenen (Eds.), Handbook of International economics (Vol. II).

Greene, W. (2000). Econometrics Analysis (4th ed.). Prentice Hall.

Gujarati, D. (2003). Basic econometrics (4th ed.). McGraw-Hill, N.Y.

Jones, R., \& Kenen, P. (1985). Handbook of International Economics (Vol. II). North-Holland, Amsterdam.

Leamer, E. E., \& Robert, M. S. (1970). Quantitative International Economics. Boston: Allyn and Bacon.

Prais, S. J. (1962). Econometric Research in International Trade: A Review. Kyklos, 15, 560-579. http://dx.doi.org/10.1111/j.1467-6435.1962.tb00075.x

Salvatore, D. (2001). International Economics (7th ed.). John Wiley and Sons.

Senhadji, A., \& Montengro, C. (1999). time series Analysis of Export Demand Equations: A cross-country Analysis. IMF Staff Papers, 46(3), 259.

Stern, R. M., Francis, J., \& Schumacher, B. (1976). Price Elasticities in International Trade. London: Macmillan Press.

Talafha, H. (1988). The balance of Trade in Jordan. Abhath Al-Yarmouk Journal, Humanities and Social Sciences, 
2(5), 7-40.

Taplin, G. B. (1973). A Model of World Trade. In R. J. Ball (Eds.), The International Linkage of National Economics Models. Amsterdam: North-Holland.

Tennakeen, T. (2010). Price and Income Elasticities of Disaggregated Import Demand in Sri Lanka. Sri Lanka Journals Online, 40(1\&2).

Uz, I. (2010). Bilateral Trade Elasticities of Turkey. International Journal of Applied Economics, 7(1), 28-46.

Via, A. (2011). Estimating Price Elasticities in International Trade: id the empirical evidence beyond proof? Department of economic and statistics, UNICAL.

World Economic Outlook Database. (2013). International Monetary Fund, 2010. Retrieved from http://www.imf.org/external/pubs/ft/weo/2013/02/weodata/weoselgr.aspx

\section{Copyrights}

Copyright for this article is retained by the author(s), with first publication rights granted to the journal.

This is an open-access article distributed under the terms and conditions of the Creative Commons Attribution license (http://creativecommons.org/licenses/by/3.0/). 